\title{
Repercussions of COVID-19 pandemic on solid waste generation and management strategies
}

\author{
Yangyang Liang ${ }^{1,3}$, Qingbin Song $(\bowtie)^{2}$, Naiqi Wu $\left.(\bowtie)\right)^{1}$, Jinhui $\mathrm{Li}^{3}$, Yuan Zhong ${ }^{2}$, Wenlei Zeng² \\ 1 Macao Institute of Systems Engineering, Macao University of Science and Technology, Macao 999078, China \\ 2 Macao Environmental Research Institute, Macao University of Science and Technology, Macao 999078, China \\ 3 State Key Joint Laboratory of Environment Simulation and Pollution Control, School of Environment, Tsinghua University, Beijing 100084, China
}

\section{H I G H L I G H T S}

- Implication of COVID-19 on medical waste and MSW generation is studied.

- Challenges and effective strategy of solid waste generation is reviewed.

- 2.9 million tons of COVID-19 related medical waste has been generated until Sep. 22 .

- The pandemic has postponed policies related to the reduction of plastic use.

- Blockade resulted in a significant drop in waste generation in some regions.

\section{A R T I C L E I N F O}

Article history:

Received 1 November 2020

Revised 24 December 2020

Accepted 20 January 2021

Available online 5 March 2021

\section{Keywords:}

COVID-19

Medical waste

Personal protective equipment

Municipal solid waste

Waste management

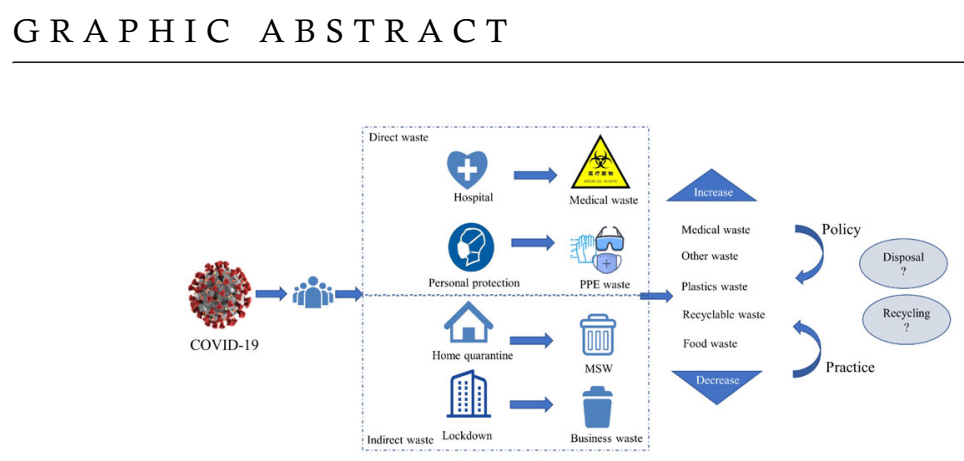

\section{A B S T R A C T}

It has been over ten months since the beginning of the 2019 coronavirus disease (COVID-2019), and its impact on solid waste management, especially medical waste, is becoming clearer. This study systematically reviews the potential influences of the COVID-19 pandemic on medical waste, personal protection equipment waste and municipal solid waste (MSW), and discusses the corresponding measures and policies of solid waste management in typical countries. The results show that the generation of medical waste from the pandemic increased significantly, with $18 \%-425 \%$ growth. It is estimated that the daily output of COVID-19 medical waste increased from $200 \mathrm{t} / \mathrm{d}$ on Feb. 22 to over $29000 \mathrm{t} / \mathrm{d}$ at the end of September 2020 throughout the world. The use of personal protective equipment will continue to grow in the long-term, while the blockade and isolation measures greatly reduced the volume of commercial waste, especially for tourist cities, and part of this waste was transferred to household waste. Residents' attitudes and behavior toward food waste have changed due to the COVID-19 pandemic. In response to the pandemic, international organizations and several countries have issued new policies and guidelines and adjusted their management strategies for medical waste and MSW treatment. The pandemic has brought specific challenges to the disposal capacity of medical waste worldwide. It has also brought about the stagnation of policies related to the reduction of plastic products and waste recycling. This study will provide some useful information for managers and governmental officials on effective solid waste management during and after the COVID-19 pandemic.

(C) Higher Education Press 2021

\section{Introduction}

The 2019 coronavirus disease (COVID-19) which has been classified as a pandemic by the World Health Organization (WHO) (WHO, 2020a) has changed the

$\triangle$ Corresponding authors

E-mail: qbsong@must.edu.mo (Q. Song); nqwu@must.edu.mo (N. Wu)

Special Issue-Zero-Waste City (Responsible Editors: Jinhui Li, Benjamin Steuer \& Xianlai Zeng) world greatly since it was first reported in early December 2019. As of 22 September 2020, it had spread to more than 215 countries and regions; over 31 million people have been diagnosed with COVID-19 all over the world (23 million have recovered) (Worldometer, 2020); and the amount of confirmed cases is still climbing. Most countries/regions have implemented complete to partial lockdowns, including home quarantines and curfews, restricted/banned international and domestic travel, prohibited public gatherings, and declared emergency status to combat COVID-19 (Lal et al., 2020). 
Besides the negative impacts on global economic activities, the response to the pandemic of COVID-19 has brought several positive environmental changes in some areas, such as the reduction of $\mathrm{CO}_{2}$ and $\mathrm{NO}_{2}$ emissions and the improvement of water quality (Eroglu, 2020; Espejo et al., 2020). However, the impacts of COVID-19 on solid waste generation and management are not inspiring. With the rapid rise in the number of confirmed cases, many types of COVID-19-related waste from hospitals, healthcare facilities, and individuals, including infected masks, gloves, and other protective equipment, are being generated during the pandemic. COVID-19 has had a significant impact on the generation of not only medical and health care waste but also of municipal solid waste (MSW) production and composition. These wastes can be divided into two types: COVID19-related waste and indirect waste (such as non-medical MSW). According to the WHO and the US CDC, COVID19-related waste can also be classified as two kinds. One is waste within hospitals and health-care facilities: all waste generated within treatment facilities should be considered medical waste and should be collected and disposed of with additional precautions and care. Another is waste outside those facilities. This includes waste from social distancing and other preventive measures (e.g., masks, gloves) (Somani et al., 2020). This last kind of waste can be treated as harmless waste.

The pneumonia outbreak of COVID-19 has greatly increased medical waste generation and the use of personal protective equipment (PPE). COVID-19 waste in the US is estimated increase from 5 million tons/year to 2.5 million tons/month (Ilyas et al., 2020), and from the pandemic outbreak to the end of April, South Korea generated 1960 tons of medical waste with the daily generated medical waste increasing from less than $10 \mathrm{t}$ to a peak of $50 \mathrm{t}$ (ESCAP, 2020). There has been a large increase in the amount of single-use plastics (including PPE) (Basel Convention, 2020a; UNEP, 2020a). Single-use plastics, also referred to as disposable plastics, are items intended to be used only once before they are thrown away or recycled, e.g., grocery bags, food packaging, bottles, etc. (UNEP, 2018). The demand for PPE (facemasks and surgical gloves) is not expected to decline during the postpandemic period, but is estimated to increase $20 \%$ up to 2025 (WHO, 2020b).

The pandemic has altered the waste generation dynamics (Ragazzi et al., 2020), with potential criticality in the waste management at the collection and treatment stages (Peng et al., 2020). Ironically, the spread of COVID-19 may be increased by inadequate waste management (WHO, $2020 \mathrm{c}$ ). Ensuring that related solid waste is collected and disposed of in a timely and orderly manner, as well as harmlessly and efficiently, has also become an important part of the battle against the pandemic (SCIO, 2020). Effective management of medical waste requires appropriate identification, collection, separation, storage, trans- portation, treatment, and disposal, as well as important associated aspects including disinfection, personnel protection, and training. The safe management of household waste is also likely to be critical during the COVID-19 emergency. PPE wastes such as contaminated masks and gloves should be stored separately from other household waste streams and collected by a municipal waste specialist or waste management operators.

Several studies have focused on the environmental impact of COVID-2019 (Table 1), analyzing the positive and negative effects on the environment including air and water quality, cleanliness of beaches and other public spaces, environmental noise level, plastic waste, medical waste, and MSW. Meanwhile, the systematic analysis with more specific information on medical waste generation, collection, treatment and management policies worldwide are still lacking. The effects on MSW and food waste generation are also unknown. This study illustrates the global challenges and proposes an effective strategy of solid waste management responding to the 2019-2020 novel coronavirus pandemic, referring to the implications of COVID-19 for solid waste generation (especially medical waste), management regulations or policies, and the responses and practices of different countries. The study also presents specific insights into the changes in the dynamics of plastic waste and food waste generation because of the pandemic, and the challenges to the current MSW management systems.

\section{Implications of COVID-19 on waste gen- eration}

\subsection{Medical waste}

\subsubsection{Changes in medical waste types and rates}

Medical waste includes waste generated from biomedical research institutions, medical institutions, and medical laboratories, as well as waste from dispersed sources (Rupani et al., 2020). Although hospitals generate large amounts of medical waste, they represent a small proportion of the total sources of waste. In general, of the total amount of waste generated by health-care activities, about $75 \%-90 \%$ is general, non-hazardous waste, such as plastic, paper and office waste. This waste can be processed through regular procedures and does not require any special handling under normal conditions (WHO, 2018; UNEP, 2020b). However, during a pandemic, as suggested, all waste generated within treatment facilities should be considered as medical waste and should be collected and disposed of with additional precautions and care. The modification of existing waste treatment facilities to manage unusual medical waste requires adequate information on the amount of medical waste generated and the treatment facilities available (Sarkodie 
Table 1 A review on the environmental effects of the COVID-2019 pandemic

\begin{tabular}{|c|c|c|}
\hline Content of the study & Scope & References \\
\hline $\begin{array}{l}\text { Waste management, air quality improvements, waste incineration, wildlife, } \\
\text { global migration, and sustainability. }\end{array}$ & Worldwide & Rupani et al., 2020 \\
\hline Ocean environment, air and water quality & Worldwide & Saadat et al., 2020 \\
\hline $\begin{array}{l}\mathrm{NO}_{2} \text { and } \mathrm{PM}_{2.5} \text {, cleanliness of beaches, environmental noise level, waste } \\
\text { generation, and waste recycling }\end{array}$ & Worldwide & Zambrano-Monserrate et al., 2020 \\
\hline Waste and wastewater & Worldwide & Nghiem et al., 2020 \\
\hline Implications of COVID-19 on plastic waste generation & Worldwide & Vanapalli et al., 2021 \\
\hline Plastic pollution due to COVID-19 pandemic & Worldwide & Patrício Silva et al., 2021 \\
\hline Plastic waste management & Worldwide & Patrício Silva et al., 2020 \\
\hline Medical waste administration & India & Ramteke and Sahu, 2020 \\
\hline Emergency response to health care wastes & China & Yang et al., 2021 \\
\hline Management of used personal protective equipment and wastes & South Korea & Rhee, 2020 \\
\hline Re-use and sustainable waste management of PPE & The Republic of Ireland & Rowan and Laffey, 2020 \\
\hline Food waste management & Spain & Aldaco et al., 2020 \\
\hline Consumer awareness, attitudes, and behaviors related to food wastage & Tunisia & Jribi et al., 2020 \\
\hline MSW management & Italy & Ragazzi et al., 2020 \\
\hline Covid-19 effects on MSW management & Brazil & Penteado and Castro, 2021 \\
\hline MSW management practices & Worldwide & Kulkarni and Anantharama, 2020 \\
\hline MSW from household, business, and industrial waste & Singapore, China, and Czech Republic & Fan et al., 2021 \\
\hline Medical waste, plastic waste, and food waste management & Worldwide & Sharma et al., 2020 \\
\hline
\end{tabular}

and Owusu, 2020b).

The waste generated in healthcare facilities can vary from 0.04 to $5 \mathrm{~kg} /($ patient $\cdot d)$. An evaluation of waste generation rate data from all over the world shows that medical waste from hospitals is about $0.5 \mathrm{~kg}$ per bed per day (UNEP, 2020c). There is no doubt that the pneumonia outbreak of COVID-19 has greatly increased the amount of medical waste, especially infectious medical waste, throughout the world. It is estimated that medical waste from healthcare facilities associated with COVID-19 is increasing by $3.4 \mathrm{~kg} /$ person/day (UNEP, 2020c). In Delhi, India, medical waste in administration or private emergency clinics has gone up from $0.5 \mathrm{~kg}$ to $2.5^{-4} \mathrm{~kg}$ per bed per day (Ramteke and Sahu, 2020). According to a case study by (Peng et al., 2020) in a Chinese hospital, the average daily output of COVID-19-related waste is more than $6 \mathrm{~kg}$ per bed per day (in a total of 24 COVID-19 patients with no deaths). At present, China produces medical waste mainly from nucleic acid detection, with an average of about $0.1 \mathrm{~kg}$ per capita, based on our field interviews.

2.1.2 Medical waste generation in typical countries and regions

As shown in Table 2 (MEE, 2020a; MHC, 2020), the rise in the cases of COVID-19 in a central city, China generated nearly $247 \mathrm{t}$ of medical waste per day at the peak of the pandemic, nearly four times more than before the pandemic. The peak occurred from Feb. 15 to Mar. 15. After that time, it gradually declined back to normal by mid-May. National collected medical waste increased from $2661 \mathrm{t}$ on Feb. 11 to about $3600 \mathrm{t}$. The wastes generated from quarantine areas are officially quantified as medical wastes. Before the outbreak, the daily domestic garbage and medical waste generated by a hospital were stored separately; during the epidemic, all garbage should be treated as medical waste, including lunch boxes used by patients $(\mathrm{Fu}, 2020)$. Therefore, the average personal medical waste during this period increased greatly. In early March, the medical waste generated in the city increased to $5.8 \mathrm{~kg} /$ (patient day) and to $11 \mathrm{~kg} /$ (patient - day) in China as a whole, based on the active cases. In fact, even the medical waste generated by suspended cases and testing takes up quite a large portion.

Other cities and countries have also suffered from the increase of medical waste generation - for example, South Korea, Spain, Iran and India (Table 3). The highest increase rate appeared in Spain; the Waste Agency of Catalonia detected a 350\% increase in COVID-19 medical waste since mid-March. Since the start of the confinement in March, it has reached 1200-925 t higher than usual (ACR, 2020). Medical waste is generated in many different facilities. According to the South Korean Ministry of 
Table 2 Medical waste generation in China

\begin{tabular}{|c|c|c|c|c|c|c|}
\hline \multirow[b]{2}{*}{ Date } & \multicolumn{3}{|c|}{ The central city } & \multicolumn{3}{|c|}{ China } \\
\hline & Active cases & Total cases & $\begin{array}{c}\text { Medical waste } \\
\text { generation }(t)\end{array}$ & $\begin{array}{l}\text { Collected medical } \\
\text { waste }(\mathrm{t})\end{array}$ & $\begin{array}{l}\text { COVID-19-related } \\
\text { medical waste }(\mathrm{t})\end{array}$ & $\begin{array}{l}\text { Accumulation from Jan } \\
\text { 21(thousand tons) }\end{array}$ \\
\hline 2.11 & - & 19558 & 47 & 2661 & 489 & - \\
\hline 2.24 & 34691 & 47071 & 201 & 2719 & 588 & 99 \\
\hline 3.1 & 25903 & 49315 & 247 & - & - & - \\
\hline 3.3 & 22368 & 49540 & 210 & 3136 & 570 & 123 \\
\hline 3.14 & 9911 & 49999 & 210 & 3300 & 458 & 15.9 \\
\hline 3.21 & 5143 & 50005 & 178 & 3475 & 380 & 182 \\
\hline 3.28 & 2045 & 50006 & 173 & 3591 & 404 & 207 \\
\hline 4.4 & 644 & 50008 & 109 & 3413 & 342 & 232 \\
\hline 4.11 & 302 & 50008 & 122 & 3481 & 237 & 256 \\
\hline 4.18 & 109 & 50333 & 99 & 3471 & 205 & 280 \\
\hline 4.25 & 12 & 50333 & 68 & 3447 & 186 & 304 \\
\hline 5.9 & 0 & 50334 & 55 & 3400 & - & 349 \\
\hline 5.16 & 6 & 50339 & 54 & 3461 & - & 374 \\
\hline 5.23 & 7 & 50340 & 65 & 3475 & - & 398 \\
\hline 5.30 & 4 & 50340 & - & 3560 & - & 422 \\
\hline 6.8 & 0 & 50340 & - & 3499 & - & 447 \\
\hline
\end{tabular}

Table 3 Medical waste generation in some regions

\begin{tabular}{|c|c|c|c|}
\hline City or Country & Medical waste generation & Cumulative cases in the research period & Source \\
\hline South Korea & By mid-July, it increased to over $2600 \mathrm{t}$ & $\begin{array}{l}27 \text { cases on Feb. } 10 \text { to } 13551 \text { cases on } \\
\text { Jul. } 15 .\end{array}$ & MoE Korea, 2020 \\
\hline Catalonia, Spain & $\begin{array}{l}1200 \mathrm{t} \text { (350\% increase), from mid-March to } \\
\text { mid-April }\end{array}$ & $\begin{array}{c}6475 \text { cases on Mar. } 15 \text { to } 142915 \text { cases } \\
\text { on Apr. } 15 \text { (Spain) }\end{array}$ & ACR, 2020 \\
\hline Tehran, Iran & $\begin{array}{l}80-110 \text { t per day during the pandemic } \\
\text { (18\%-62\% increase) }\end{array}$ & $\begin{array}{c}54 \text { cases on Mar. } 1 \text { to } \\
2750 \text { cases on Mar. } 30 \text { (Iran) }\end{array}$ & Zand and Heir, 2020 \\
\hline Ahmedabad, India & $\begin{array}{c}1000 \mathrm{~kg} / \mathrm{d}(67 \%-82 \% \text { increase }) \text {. } \\
3000 \mathrm{~kg} / \mathrm{d} \text { in the future }\end{array}$ & - & TOI, 2020 \\
\hline
\end{tabular}

Environment (MoE), from early February 2020 to early March 2020, approximately 295 t of COVID-19 medical waste was generated from quarantine hospitals (180.6 t), temporary isolation facilities $(61 \mathrm{t})$, isolated life treatment centers for patients (39t) and community treatment centers (15 t) (MoE Korea, 2020). Based on the above information, it is calculated that the average medical waste generation during the pandemic has varied from 2.5 to $5.8 \mathrm{~kg} /($ patient $\cdot$ day); $4 \mathrm{~kg} /($ patient $\cdot$ day) has been chosen here, to estimate medical waste generation in different areas and dates in the following section.

\subsubsection{Estimation of medical waste generation worldwide}

Medical waste generation data are used to estimate the required capacity of the waste treatment facilities, and also to optimize the waste management systems and carry out national assessments and planning. The waste generation rate in healthcare facilities is affected by several factors such as number of occupied beds, average length of stay of patients, location (rural or urban), procurement policies, temporal variations, and the country's level of development (Basel Convention, 2020b). To estimate the total medical waste generation related to COVID-19 around the world, a simplified method is used, and some assumptions are made here: 1) medical waste generation increased to $4 \mathrm{~kg} /$ (patient - day) during the COVID-19 pandemic; 2) the daily increase number of active cases in each month is fixed and the start date is Jun. 22; 3) The medical waste from routine nucleic acid detection is not included. The calculation for daily waste generation is shown in Eq. (1):

$$
W_{\text {Daily }}=C \times \mathrm{w}_{\text {Average }}
$$

where $W_{\text {Daily }}$ is the medical waste amount in a specific day, 
$C$ refers to number of active cases on that day, and $\mathrm{w}_{\text {Average }}$ represents the average waste generation $(4 \mathrm{~kg} /$ (patient - day)). The monthly cumulative generation is estimated by the sum of daily waste generation.

The estimation is shown in Fig. 1(A): 2 tons of COVID19-related medical waste was generated on Jan. 22, and the data increased to about 29825 t on Sep 22. The monthly medical waste generation increased from 3391 tons to 852000 tons. In total, 2.9 million tons of COVID-19related medical waste has been generated during the last 8 months. Using a lower waste generation rate $(0.5 \mathrm{~kg} /$ (patient-day), the average generation rate before the pandemic) the total amount is estimated as 0.4 million tons. Medical waste generated in different countries by the end of September is shown in Fig. 1(B); only countries generating over 100 tons/day are included. The US generated more than 10000 tons on Sep 30, far more than other countries, and India, Brazil, and France generated 1690, 2009, and 3776 t, respectively.

\subsection{PPE waste}

PPE is considered the most reliable and affordable defense against infection and transmission of the virus. At the beginning of the pandemic, to prevent the spread of the virus, PPE - such as medical masks and gloves - was used mainly by healthcare professionals. But with the growing spread of the virus, those PPE items have become mandatory for the entire population in many countries.

Millions of PPE are being manufactured and used daily by ordinary citizens during the pandemic (Table 4). For example, the Republic of Ireland is a small country with a population of about 4.5 million, but its health workers use up 9 million masks a week (Farsaci, 2020). However, the
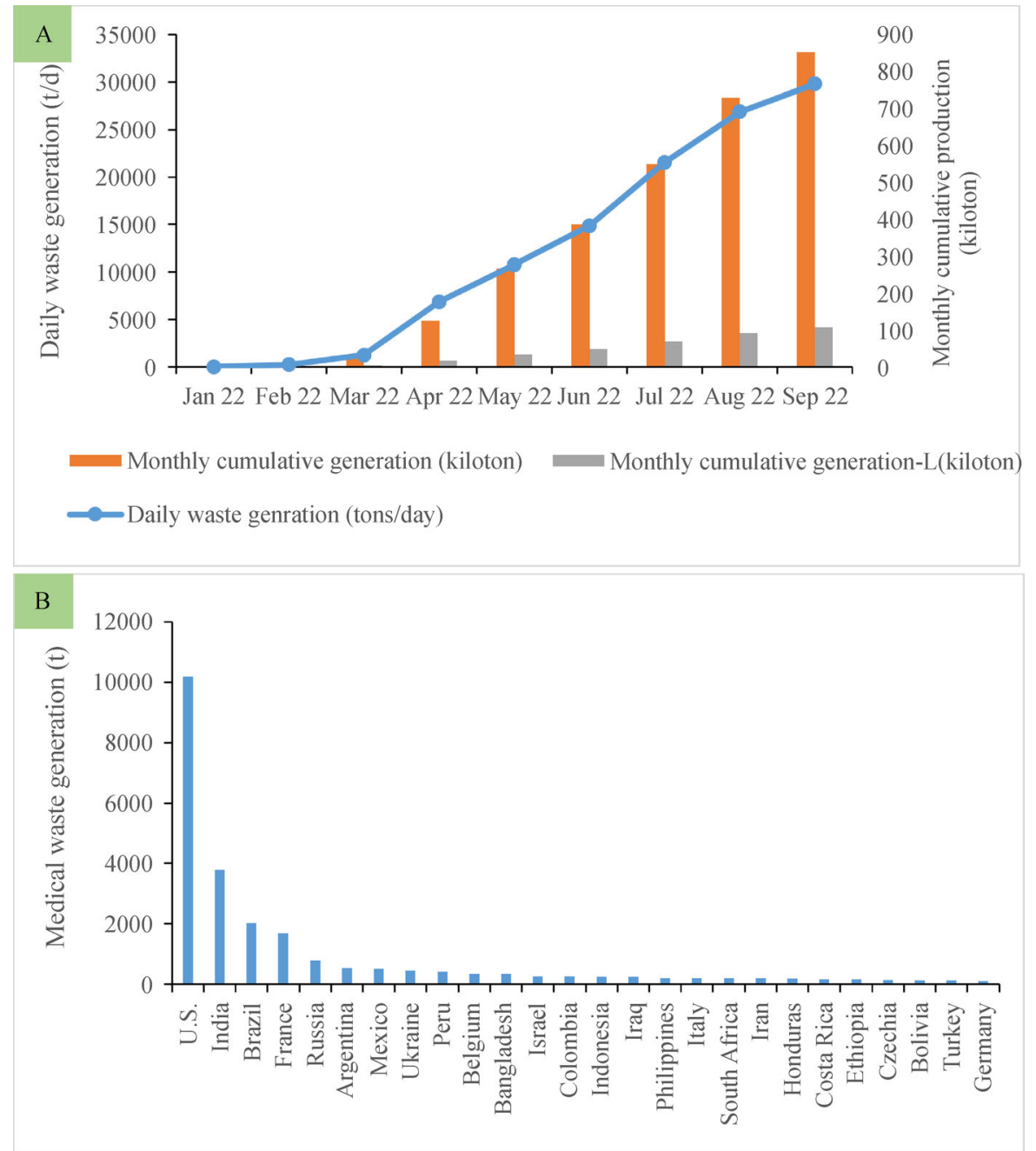

* Monthly cumulative generation - L menns the daily waste generation is $0.5 \mathrm{~kg} /$ patient

Fig. 1 Estimation of COVID-19-related medical waste generation around the world. A. Medical waste generation on different dates; B. Medical waste generation in different countries on Sep 30, 2020 (any country with daily medical waste over $100 \mathrm{t}$ ). 
Table 4 Estimation of number of masks used in some studies

\begin{tabular}{lccc}
\hline Region & Estimated data & Condition & Reference \\
\hline The Republic of Ireland & 9 million masks/week & Used by health workers & Farsaci, 2020 \\
Africa & 700 million masks/day & $80 \%$ acceptance rate and an average of 2 face masks daily & Nzediegwu and Chang, 2020 \\
Tehran, Iran & 5.5 million masks/day & $32 \%$ of the residents of Tehran agreed to use PPE & Zand and Heir, 2020 \\
Italy & 40 million masks/day & Two-thirds of the whole population are wearing masks & Ragazzi et al., 2020 \\
\hline
\end{tabular}

use of PPE by ordinary citizens also makes up a major part of the total. More than 50 countries/territories have mandated compulsory facemask use for their citizens (Sarkodie and Owusu, 2020b). Italy would normally dispose of about 40 million masks daily, with a total amount of about 44,000 tons. This amount is $0.14 \%$ of the national total MSW, and when 40 million pairs of singleuse gloves are included, the ratio of PPE used by citizens would increase to $0.59 \%$ (Ragazzi et al., 2020). Based on these data, the impact of millions of PPE seems to be not much, considering MSW management at the national level alone. But because this PPE, along with its possible residual viruses, is easily blown away into open water by the wind, their management cannot be ignored.

A mask is mainly composed of plastic $(>80 \%)$ (Prata et al., 2020), and thus the increased demand for single-use PPE by healthcare professionals and the mandated use of masks for the public have transformed the dynamics of plastic waste generation. Indirectly, the COVID-19 pandemic has enhanced the complexities of plastic waste management and seems to hamper the efforts to reduce plastic pollution (Vanapalli et al., 2021; Sarkodie and Owusu, 2020b).

\subsection{MSW generation}

\subsubsection{Plastic waste}

The concerns about the survival of the virus have changed our behavioral patterns. Along with lifestyle changes that increase plastic use for convenience and reassurance, consumers have shifted from worrying about plastic waste's environmental impacts to preferring plastic packaging for hygiene and health reasons, during the pandemic (Grodzińska-Jurczak et al., 2020).

In the beginning, the sudden lock-in and fear of the virus led to a surge in disposable products and panic purchases (Sarkodie and Owusu, 2020a). Demand rose sharply for packaging for groceries, healthcare products, and ecommerce transportation (Feber David 2020). The demand for consumer-packaged goods grew by $9.5 \%$ in the United States, which may be attributable to consumers stockpiling food (Statista, 2020).

The quarantine policies established in most countries/ regions have also caused consumers to increase their demand for online shopping and food delivery services (Rupani et al., 2020; Rhee, 2020; Vanapalli et al., 2021). Compared to the reference period in January and February 2020, the online trading across 20 different industries increased in June, and even though it decreased on September 6, online transactions still increased (16.6\%) compared to the index period (Clement J., 2020). According to the Korea Statistics Bureau, online shopping for household goods and food delivery services increased by approximately $20 \%$ (Statistics Korea, 2020). All these changes in consumption habits have increased the amount of plastic waste generation.

\subsubsection{Food waste generation}

COVID-19 has exerted a certain influence on food loss and waste (FLW) because of the consumption habits and food production changes it has caused. In a survey of US households $(n=1005)$ in April 2020 (Hunter, 2020), it was found that the number of households cooking at home was $54 \%$ more than before COVID-19, which may imply more food waste, but $57 \%$ also reported that they were wasting less food, which suggests that the net effect could amount to no or little change in the organic waste stream.

During an uncertain situation such as the COVID-19 pandemic, individuals with higher cognitive closure (NFC) waste more food compared with people with low NFC. This effect is caused by the feeling that there is a shortage of food, resulting in unnecessary food purchases (Brizi and Biraglia, 2021). Consumption data in Spain shows that food purchases increased in the first two weeks of the lockdown (29.8\% and $10.9 \%$ increases), then decreased $20.3 \%$ in the third week. The COVID-19 outbreak had a slight influence on the total amount of FLW in Spain: FLW generation in households increased by $12 \%$ (Aldaco et al., 2020). But if it is true that non-household consumption was absorbed by households during the outbreak, the overall amount of FLW generated is still similar to that in 2019.

The COVID-19 lockdowns have also an impact on consumers' awareness, attitudes and behaviors. In an online survey in Tunisia, 85\% of the respondents said that they would not discard what they bought, and $93 \%$ of the respondents wanted to try to control their food waste levels during the COVID-19 lockdown. The prevention of food 
waste may, however, be due more to the socio-economic context of the COVID-19 crisis (i.e., food supply, limited mobility, loss of income) than to environmental concerns (Jribi et al., 2020).

\subsubsection{MSW generation data}

The announcement of the lockdowns and travel restrictions resulted in a significant drop in waste generation in some regions (Table 5), especially tourist cities. Due to the high concentration of labor, commercial and tourist activities in cities that are now closed or have reduced activity, waste generation in Barcelona fell by $25 \%$. MSW generation in Macao, a typical tourist city in China, decreased $17 \%-25 \%$ between February and May. In Milan, Italy, the strict blockade system resulted in a $28 \%$ reduction in total waste production in 10-14 weeks, 2020, including a $24 \%$ reduction in residual waste, household food waste reduction of $14 \%$, and commercial food waste reduction of over $80 \%$.

Another reason for the decline in waste generation is the reduction of recycling activities: citizens accumulate some MSW at home rather than at collection centers. In India, recycling activities have been stopped, and the amount of MSW reaching landfills/junkyards decreased by $20 \%-40 \%$ (Somani et al., 2020). MSW generation in Catalonia, Spain has fallen to about $17 \%$ lower than in a normal month.

On the other hand, the pandemic has increased waste generation in other areas. In England, a survey of local governments in late May 2020 found that more than $90 \%$ of local authorities reported higher waste generation and waste collection than usual, and 58\% reported increases to be in the range of $0 \%-20 \%$ greater than normal (ADEPT,
2020). The social distancing measures of COVID-19 led to the closure of businesses and schools, reducing waste generation, but transferred part of the waste to households (Naughton, 2020). In Tokyo, Japan, the commercial waste amount decreased by $57 \%$ in May, 2020, while the household waste amount increased by $110 \%$.

\section{Response to waste management and treatment systems}

The regions with high COVID-19 incidence rates are struggling to manage the dramatic increase in the amount of medical waste generated in the treatment, personal protection and testing processes (Klemeš et al., 2020). However, many developing countries were already facing poor management of medical waste before the COVID-19 pandemic (Rahman et al., 2020). In some countries, medical wastes along with MSW are dumped in the open or in poorly managed landfills (Nzediegwu and Chang, 2020). In addition, open burning and incineration without proper pollution control expose waste workers and surrounding communities to toxic pollutants from air emissions and ash. In India, the net generation of medical waste is 405 tons/day, of which just 292 tons/ day is disposed of, implying that practically $28 \%$ of the wastes are left untreated (Ramteke and Sahu, 2020). According to the Asian Development Bank, these cities like Manila, Kuala Lumpur, Hanoi, and Bangkok would produce 154-280 tons/day of medical waste, and few cities have the capacity to deal with these expected excessive amounts of waste (ADB, 2020). To deal with the huge increase in medical waste generation, it is crucial to update

Table 5 MSW generation in different regions

\begin{tabular}{|c|c|c|}
\hline Country or city & Generation & Source \\
\hline Macao, China & $\begin{array}{l}\text { From February to May, the MSW generation decreased by } 17 \%-25 \% \text {, } \\
\text { compared to } 2019\end{array}$ & $\begin{array}{l}\text { Environmental Protection Bureau (DSPA) } \\
\text { Macao SAR, } 2020\end{array}$ \\
\hline $\begin{array}{l}\text { Khenifra and Tighassaline, } \\
\text { Morocco }\end{array}$ & $\begin{array}{l}\text { February and March 2020, compared to the same period of 2019, the MSW } \\
\text { generation has decreased } 2 \%-10 \%\end{array}$ & Ouhsine $\mathrm{O}, 2020$ \\
\hline Catalonia, Spain & MSW generation has fallen to an estimated $242000 \mathrm{t}, 17 \%$ & Generalitat de Catalunya, 2020 \\
\hline Milan, Italy & $27.5 \%$ reduction in total waste production & AMSA, 2020 \\
\hline Trento, Italy & 4058 t, $14 \%$ lower than March 2019 & Ragazzi et al., 2020 \\
\hline India & $\begin{array}{l}\text { The amount of MSW reaching landfills/junkyards decreased by about } 20 \%- \\
\qquad 40 \%\end{array}$ & Somani et al., 2020 \\
\hline New York, US & Residential solid waste generation increased from 5 to $30 \%$ & WasteAdvantage, 2020 \\
\hline & Commercial and industrial sector waste decreased by as much as $50 \%$ & \\
\hline \multirow[t]{2}{*}{ Tokyo, Japan } & $\begin{array}{c}\text { After Japan declared a state of emergency on } 7 \text { April 2020, the commercial } \\
\text { waste amount decreased by } 57 \% \text { in May }\end{array}$ & UNEP, 2020c \\
\hline & The household waste amount increased by $110 \%$ in May & \\
\hline England & $\begin{array}{c}\text { May } 2020,58 \% \text { reported increases to be in the range of } 0 \%-20 \% \text { greater than } \\
\text { normal }\end{array}$ & ADEPT, 2020 \\
\hline Tehran, Iran & Landfilling of wastes in Tehran has increased by $34.7 \%$ & Zand and Heir, 2020 \\
\hline
\end{tabular}


management strategies and rapidly increase the disposal capacity.

3.1 Policies and practices regarding medical waste during the COVID-19 pandemic

\subsubsection{International guidelines}

Waste generated during the pandemic has raised concerns regarding the potential role of waste residues in spreading the infection (Ragazzi et al., 2020). Some international organizations, such as the WHO, the Basel Convention, European Centre for Disease Prevention and Control (ECDC), and the United Nations Environment Programme (UNEP), have published the guidelines or reports on the correct management of medical waste and waste produced in households (Table 6) (Basel Convention, 2020c; ECDC,
2020; European Commission, 2020; ISWA, 2020; UNEP, 2020c; UNICEF, 2020a; 2020b)

The Basel Convention's guidance document-Factsheet on Environmentally Sound Management of Medical Waste-provides the information on how to manage medical waste in the most sustainable manner. This fact sheet is primarily intended for the use by waste managers at facilities generating or disposing of medical waste, but it also contains useful information for transporters and collectors. The WHO has provided information on hygiene practices, along with guidance on how to safely manage manure and wastewater, maintain the quality of the water supply, and manage medical care and household waste generated by quarantined personnel (UNICEF, 2020a; 2020b). Waste Management during the COVID-19 Pandemic: from response to recovery reviews current management practices for the waste from healthcare facilities,

Table 6 The responding policies and guidance plans to the COVID-19 pandemic

Guidelines and policies
- Water, sanitation, hygiene, and waste management for the COVID-19 viru
interim guidance
- Water, sanitation, hygiene and waste management for COVID-19: technic
brief
- Waste Management during the COVID-19 Pandemic: from response to
recovery.

- Factsheet on Environmentally Sound Management of Medical Waste

- Waste Management During the COVID-19 Pandemic

- Infection prevention and control in the household management of people with suspected or confirmed coronavirus disease (COVID-19)

- Waste management in the context of the coronavirus crisis

- Guide on Management and Techniques of Emergency Treatment and Disposal of Medical Waste Caused by COVID-19 (Trial).

- Notice on the Management of Medical Waste in Medical Institutions for COVID-19

- Work Plan for Comprehensive Waste Management in Medical Institutions

- Coronavirus (COVID-19): disposing of waste

- COVID-19 waste management standard operating procedure

- Cleansing and PPE waste at a healthcare waste management facility: RPS

$\mathrm{C} 1$

- PPE waste from home healthcare workers treating patients with COVID-19: RPS C5

- Extraordinary measures for Safety Management of Wastes Related to COVID-19

- Guidelines for waste treatment in residential treatment centers

- Guidelines for Handling, Treatment, and Disposal of Waste Generated during Treatment/Diagnosis/Quarantine of COVID-19 Patients

- Guidelines for the novel coronavirus infectious wastes

\begin{tabular}{cc} 
Institution or country & Main content \\
\hline WHO & $\begin{array}{c}\text { WHO's guidance on virus-related water supply, sanita- } \\
\text { tion, personal hygiene, and waste management for } \\
\text { various types of viruses, including coronavirus. }\end{array}$
\end{tabular}

UNEP

Practical information, suggestions, and guidelines on Medical Waste Management and Municipal Solid Waste Management

Basel Convention Supports the implementation of the environmentally sound management of hazardous wastes and other wastes.

ISWA

Recommendations on three priorities for waste management

ECDC Management of household waste

EC Provides guidance on preventing and reducing disruptions in the provision of proper waste management services.

China Management and technical guidelines on emergency treatment of medical waste for institutions

UK Waste management approach for all healthcare facilities; How to dispose of personal or business waste, including face coverings and PPE

South Korea

Provides detailed management processes for medical waste from different sources

India Provides guidance on segregation of general solid waste and biomedical waste and recommead on disposal of PPEs

Japan Types and characteristics of COVID-19 waste; messages when dealing with medical waste 
households, and quarantine locations (UNEP, 2020c). A series of COVID-19 Waste Management Factsheets were published by the UNEP, to give instructions on aspects such as national medical waste capacity assessment and how to choose the best COVID-19 waste management technology (UNEP, 2020a).

3.1.2 Typical medical waste management policies and processes

Some governments have existing national legislation addressing healthcare/medical waste. Also, many countries immediately issued some new policies, guidance, and plans to respond to the COVID-19 pandemic (Table 6) (BCRC China, 2020; MoE Japan, 2020; GOV.UK, 2020a). Countries like China, and South Korea, have carried out the effective and successful measures for COVID-19 medical waste management. The lessons and successful measures that China gained from COVID-19 medical waste management could provide valuable information for many developing countries coping with a sudden increase in medical waste.

\subsubsection{China}

In response to the COVID-19 epidemic, China central government issued Guide on Management and Techniques for Emergency Treatment and Disposal of Medical Waste Caused by COVID-19 (Trial) (MEE, 2020b) and Notice on Environmental Management of Medical Waste Caused by COVID-19 (NHC, 2020). They provide guidance to dispose of the COVID-19medical waste in a timely and orderly manner, as well as harmlessly and efficiently, and to standardize the management and technical requirements. Even, some provinces also issued special COVID-19 waste management guidelines.

Waste from infected patients or suspected cases should be managed according to the Fig. 2. Medical waste classification is the first step in hospital waste management. Medical waste and domestic waste generated by fever clinics, observation wards, isolation wards, and nucleic acid testing laboratories should be treated as COVID-19-related medical waste (Peng et al., 2020). Medical and health institutions with adequate facilities can store infectious medical waste separately. The storage place should be disinfected, and the temporary storage time should not exceed $24 \mathrm{~h}$. To carry out the disposal of medical waste caused by pneumonia, facilities, the sufficient preparation in health and epidemic prevention must have been done, based on the requirements specified by health authorities.

\subsubsection{South Korea}

In the early stages of the epidemic, South Korea was one of the countries with the highest number of infected cases, ranking in the top five. Since March 2020, the number of cases nationwide has dropped significantly. Since the first infected case was confirmed on Jan 20 in South Korea, the MoE announced the first version of Extraordinary measures for Safety Management of Wastes Ralated to COVID-19 on Jan 28 (Ilyas et al., 2020).

According to the new guidelines (MOHW, 2020), COVID-19-related waste cannot be stored more than 24 $\mathrm{h}$ and should be incinerated on the day of collection. The storage time and incineration time were both cut down compared with those in the earlier act, in which the maximum storage time was 7 days and the waste only needed to be incinerated within 2 days of delivery. Figure 3 presents the detailed management processes for medical waste f. Waste from hospitals and residential treatment centers is to be treated as separate medical waste and controlled with the strictest measures. Waste management during self-quarantine varies according to the infection situation and the period of patient illness. Under the

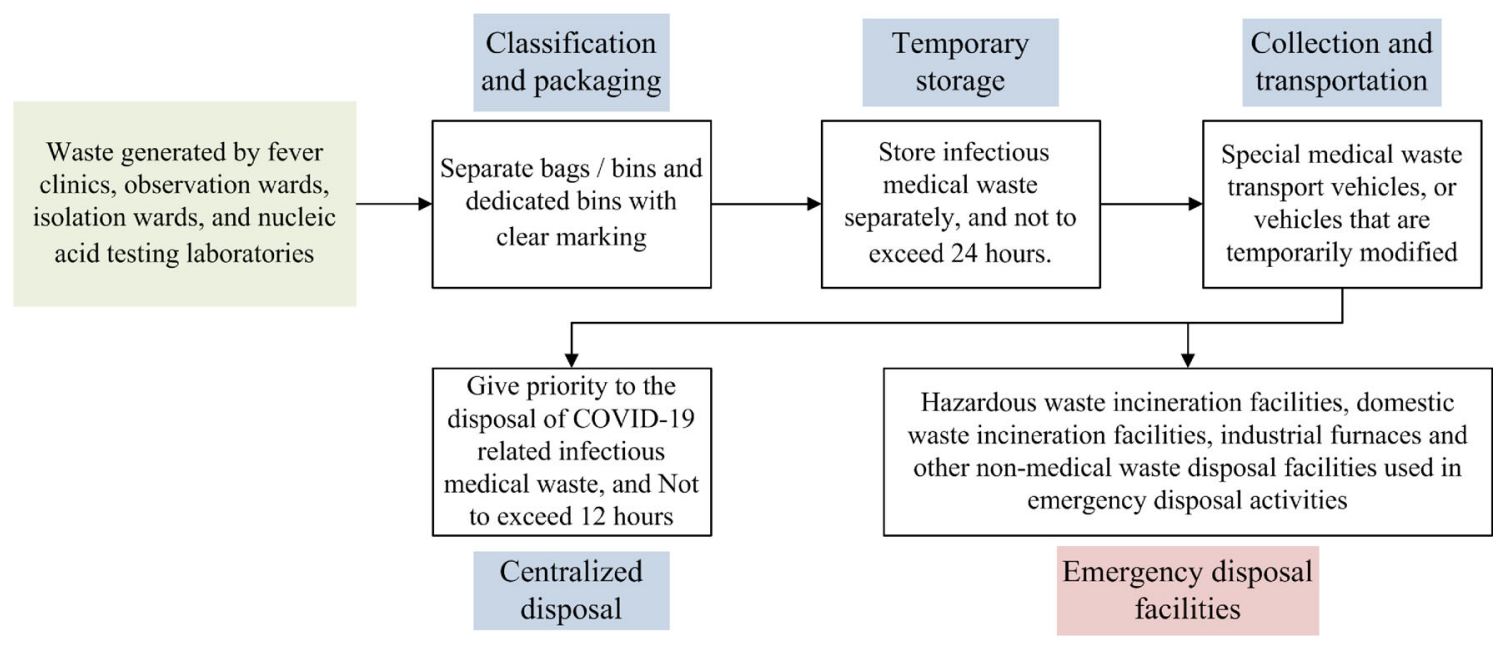

Fig. 2 Emergency disposal process and technical points in China. 


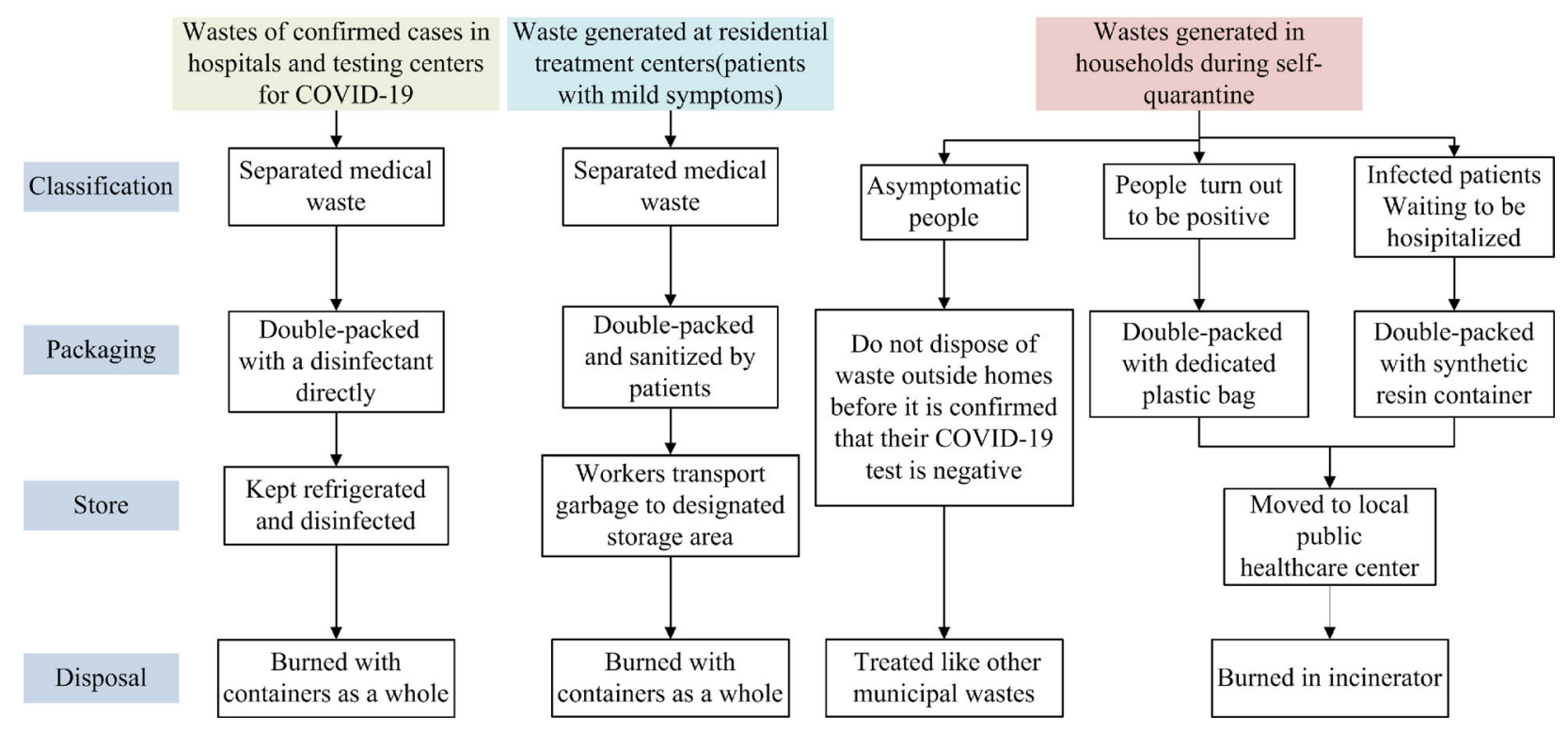

Fig. 3 Medical waste management system in South Korea (extract and organize from ESCAP, 2020).

extraordinary measures, the household waste from selfquarantined persons should also be treated as COVID waste (ESCAP, 2020).

\subsubsection{Medical waste treatment processes in other coun-} tries

Currently, India has limited facilities for dealing with medical waste. Responding to the sudden increase in medical waste is a huge challenge for local authorities. On March 18, 2020 the Central Pollution Control Board, New Delhi released a set of guidelines on dealing with the waste from diagnosis, treatment, and isolation of COVID-19 patients (Ramteke and Sahu, 2020). In this case, the isolation ward of the hospital needs to maintain independent light-shielded coded tanks to isolate the waste. A special container labeled "New Coronary Pneumonia" should be placed in a different, temporary additional space and access to it should be controlled.

In Iran, due to the COVID-19 pandemic, the disposal of infectious waste in hospitals has completely stopped. Although the medical waste in Tehran is supposed to be divided into four categories - non-hazardous waste, medicines/chemicals, infectious waste, and sharp waste, only $47.3 \%$ hospitals are satisfactorily following these guidelines. Currently, hospital waste is collected in double or triple bag bags and transported to the Aradkouh treatment site, where it is buried in designated ditches (compacted waste sprayed with hydrated lime) (Zand and Heir, 2020).

In Romania, the National Institute of Public Health announced that household waste generated in quarantine sites is infectious waste (March 18, 2020), and strict waste management procedures must be implemented. These wastes must be collected by specialized waste operators and transported, at $-4^{\circ} \mathrm{C}$, to hazardous waste incinerators (Mihai, 2020).

Information from the CDC, US shows that medical waste from healthcare facilities treating COVID-19 patients is no different from other medical waste and should be processed following routine procedures. Medical waste and infectious waste are subject to state solid waste regulatory programs (CDC, 2020; TCEQ, 2020).

Comparing the management policies and treatment processes in different countries, taking China and Korea as examples, it can be seen that besides the basic classified collection, double packaging, storage, and disposal, there are some differences because of local situations. In Korea, different collection and disposal processes are adopted depending on the source of the medical waste, such as from hospitals, residential treatment centers and self-quarantined households, while in China there are stricter requirements on the disposal time, which is not to exceed $12 \mathrm{~h}$. China also gives clear guidance for emergency treatment priorities, diversion mode and treatment facilities. Differences also exist in the disposal technologies, as will be discussed in the following section.

\subsubsection{Disinfection and disposal technologies}

Different disinfection and disposal methods should be adopted based on various factors such as the quantity and type of waste, and the disposal and maintenance costs. A comprehensive introduction of disinfection and disposal technology is shown in Table 7 (Ilyas et al., 2020; Wang et al., 2020). The common incineration technologies include pyrolysis vaporization incinerators, rotary kiln incinerators, plasma incineration technology, etc. In 
Table 7 Disinfection techniques for medical wastes

\begin{tabular}{|c|c|c|c|c|c|}
\hline Technologies & Specific technologies & Characteristics & Waste volume & Costs & Maintenance \\
\hline Chemical disinfection & $\begin{array}{l}\text { Sodium hypochlorite, calcium } \\
\text { hypochlorite, chlorine dioxide }\end{array}$ & $\begin{array}{c}\text { Broad sterilization spectrum, rapid and stable } \\
\text { performance; Residual disinfectants after } \\
\text { disinfection. }\end{array}$ & $<10 \mathrm{t} / \mathrm{d}$ & Low & Easy \\
\hline \multirow[t]{2}{*}{ Physical disinfection } & Microwave disinfection & $\begin{array}{l}\text { Low action temperature, energy-saving, slow heat } \\
\text { loss, and less pollutant release without gaseous } \\
\text { emissions; relatively narrow disinfection spectrum } \\
\text { and complex impact factors of disinfection. }\end{array}$ & $<10 \mathrm{t} / \mathrm{d}$ & High & Complex \\
\hline & $\begin{array}{l}\text { High-temperature steam } \\
\text { disinfection }\end{array}$ & $\begin{array}{l}\text { Available in various volumes, using heat released by } \\
\text { water vapor to make pathogenic microorganisms } \\
\text { undergo protein denaturation and coagulation; weak } \\
\text { odor control. }\end{array}$ & $<10 \mathrm{t} / \mathrm{d}$ & Low & Easy \\
\hline \multirow[t]{3}{*}{ Incineration } & $\begin{array}{l}\text { Pyrolysis vaporization } \\
\text { incinerator }\end{array}$ & $\begin{array}{l}\text { The organic components of the waste are decom- } \\
\text { posed into flammable gases in order to avoid dust } \\
\text { due to the turbulence caused by the excess air; high } \\
\text { investment costs and strict requirements on heat } \\
\text { levels of wastes, potential emission of carcinogens. }\end{array}$ & $>10 \mathrm{t} / \mathrm{d}$ & High & Easy \\
\hline & Rotary kiln incinerator & $\begin{array}{l}\text { Enables the wastes to be well mixed, improves } \\
\text { incineration efficiency; high dust content in the } \\
\text { exhaust, high air volume requirements, high invest- } \\
\text { ment and maintenance costs, potential emission of } \\
\text { carcinogens. }\end{array}$ & & & \\
\hline & Plasma incineration & $\begin{array}{l}\text { Transfers energy through plasma; wastes can be } \\
\text { quickly decomposed into small molecules and even } \\
\text { atoms. High requirement for technical personnel and } \\
\text { high costs, potential emission of carcinogens. }\end{array}$ & & & \\
\hline
\end{tabular}

general, a combination of chemical disinfection and incineration should be adopted. The waste treated by physical disinfection can end in a municipal landfill. However, some countries require the waste to be rendered unrecognizable. Specific treatments are still needed depending on local legal regulations (Basel Convention, $2020 \mathrm{~b}$ ). Incineration is one of the most widely used technologies, as it is safe, simple, and effective (Wang et al., 2020).

In addition to the choice of disinfection and disposal technologies, another question is whether to use on-site, mobile, or off-site treatment. If the existing systems for medical waste treatment are overloaded, industrial furnaces and cement kilns could be appropriated for use (ADB, 2020). In China, on-site and mobile treatments are considered to be preferable due to their flexibility in responding to shifting demands. There have always been advantages and drawbacks to all ways, and the policies are also subject to context-specific constraints (Klemeš et al., 2020).

The medical waste generation in a central city, China far exceeded the existing treatment capabilities soon after the pandemic began. Fixed facilities, mobile facilities, coprocessing facilities (MSW incineration plants), and nonlocal disposal were all successively used. Mobile facilities and non-local disposal (2.6\% of waste was sent to nearby cities for harmless disposal) are auxiliary means (Yang et al., 2021). Mobile incinerators can be used to dispose of discarded PPE such as face masks, gloves, and other contaminated single-use protective gear (Chen and Guo, 2020). The waste disposal capacity has now achieved 280 $\mathrm{t} / \mathrm{d}$, while before the COVID-19 outbreak, the medical waste disposal capacity is about $50 \mathrm{t} / \mathrm{d}$. These practices can provide the reference models for other densely populated metropolises.

\subsection{MSW management adjustments}

The survival time of coronaviruses on the surfaces of metal, glass, and plastic surfaces is in the order of days (up to 9 d) (Kampf et al., 2020a, 2020b), indicating that the waste from households with positive or suspected COVID19 patients may contain viable SARS-CoV-2 and could be a source of infection for some time (Nghiem et al., 2020). Waste collection and handling may pose a risk to MSW operators if they are exposed to waste contaminated by infected individuals (Ragazzi et al., 2020). In this section, the different responses to MSW management are summarized. PPE waste, as the most representative waste, is discussed separately.

\subsubsection{PPE waste management}

In South Korea, the used masks from a household can be placed in a regular garbage bag under the volume-based waste fee (VBWF) program. Waste containing used masks 
must be incinerated or landfilled; no recycling is allowed (Rhee, 2020). In the UK, if the residents belong to the selfisolating people, their masks or PPE waste should be put into a double bag and stored for $72 \mathrm{~h}$ before putting them in a 'black bag' waste bin; otherwise, the masks and PPE are disposed of in a 'black bag' waste bin without extra bags or special storage. Businesses or other organizations, however, do not need to collect PPE separately (GOV.UK, 2020b). The Portuguese Environment Agency recommends that all PPE waste from ordinary citizens should be treated as mixed waste (rather than recyclables), placed in sealed and leak-proof garbage bags, and may then enter incineration facilities (preferably) or landfilled daily (Patrício Silva et al., 2021).

China has not issued any national guidelines on the management of PPE waste. Instead, some provinces have published a local technical guide for PPE waste management. For example, in Sichuan province, the used masks should be collected and disinfected before the incineration. In Guangdong, on the other hand, for ordinary people, their masks can be directly thrown into the "other garbage" bin, but the recycling and reuse are strictly prohibited.

The guidance from the CDC, the Occupational Safety and Health Administration, and a few state agencies of the US shows that the waste with potential risk of COVID-19 contamination should be managed like any other MSW. The fact sheet for Oregon, US - Managing COVID-19 Solid Waste - also notes that the state's rules generally consider PPE waste, cleaning, and disinfection waste (outside the medical and healthcare industry) as general solid waste (PeRKINS Coie, 2020).

Compared with some of the treatment methods for PPE waste, the effective collection could play the most important role in waste management. The used masks, if incorrectly disposed of - e.g., in open landfills or waters, will likely degrade into smaller plastic pieces, even microplastics. During a survey on the Soko islands, masses of surgical masks were found along the shoreline (OCEANSASIA, 2020).

\subsubsection{MSW collection and recycling}

Although the ratio of waste that may contain viable SARS$\mathrm{CoV}-2$ is lower in MSW than in medical waste, its infectious risk cannot be ignored. MSW management differs depending on whether there are confirmed or suspected cases within a household. Most countries, such as in Romania (Mihai, 2020), follow the guidelines from UNEP and ECDC. In Italy, according to the Italian Health Institute guidelines (ISS, 2020), the MSW from a dwelling place with an infected person must be regarded as the residual MSW and disposed of in a separate bag. If there are no infected persons in the dwelling place, the household can continue to carry out undifferentiated collection just as before the pandemic.
Many countries have reached a consensus that the recycling process has very low risk and that the recyclable waste is unlikely to be infected with coronavirus. Thus, waste collection and recycling can be processed by the original process before the pandemic, but if the waste is contaminated, it must be collected in sealed bags or containers (Ikiz et al., 2021; Finnish Goverment, 2020; Swedish EPA, 2020). In Finland, this situation will not lead to changes in current household classification practices. The health authorities in Germany classify the transmission risk of waste collection and disposal as low (Waste Minz, 2020).

In China, the suspected and confirmed patients are concentrated in special places. Thus, the possibility of infectious waste from households is lower, and the primary need is the effective management of PPE waste. For such areas like China, the classification and recycling of MSW is not necessary. However, in some countries - those with an excessive number of patients or a lack of sufficient medical resources - or in areas where a policy of keeping patients at home is adopted, the infectious wastes, such as those that may be contaminated with bodily fluids and protective equipment, need to be separately bagged.

In other places, local authorities have suspended the part of waste recycling in some stages. A non-statutory guideline from the British Government gives the guidance on waste collection priorities during the coronavirus pandemic (Fig. 4)(GOV.UK, 2020a).

\section{Rethinking effective waste management under the COVID-19 pandemic}

\subsection{National medical waste capacity assessment}

There is no singular solution; for different countries or regions varying in number of infected cases, medical resources, isolation measures, and waste types, different solutions should be adopted. There are many challenges in dealing with timely and effective waste management. The management of medical waste involves many departments and a large number of individuals, requiring interdepartmental collaboration. In order for a country to determine whether it is capable of managing a significant increase in medical waste generation, it should compile a summary of the existing policies, regulations, and infrastructures, as well as its current operation status for dealing with medical wastes. For many developing countries that may not have detailed or adequate policies, policies and guidance from international institutions on medical waste can be adopted. The real problem is not, therefore, how to formulate these policies but how to successfully implement them. That requires mobilizing government efforts and resources. When the medical waste disposal capacity cannot be improved quickly enough, adequate disinfection should play a more important role. 


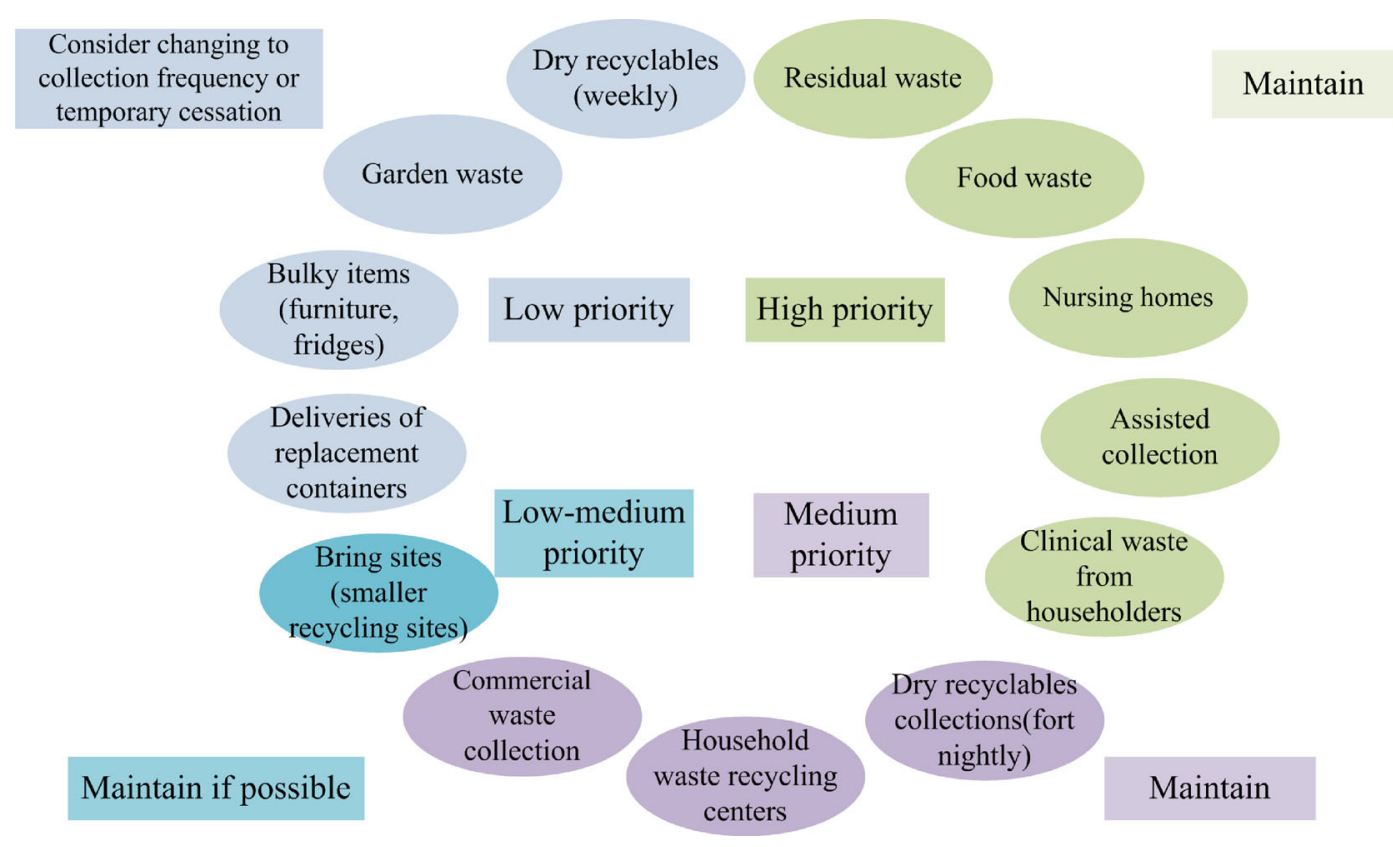

Fig. 4 Guidance on waste collection priorities (extract from the guidance of the Department for Environment Food and Rural Affairs, GOV.UK,2020a).

\subsection{MSW classification, recycling and recovery}

Waste collection have been influenced due to the decreasing staff availability. The suspension of recycling activities in some regions has resulted in an increase in mixed waste, creating some serious challenges to waste classification habits and the recycling industry. Citizens need to be informed whether it is necessary to continue the source separation of MSW, and recycling services should be restored as soon as possible. A large number of informal recyclers, throughout the world, are facing the exposure risks because of lack of the protective masks or gloves and safety awareness. Governments need to be aware of this category of waste processors and implement the effective strategies to control the potential risks. In many places, MSW management problems may have shifted to rural areas. For example, just before the French adopted lockdown measures, many urban residents moved to their secondary rural residences, increasing the pressure on rural waste management capabilities (Dente and Hashimoto, 2020).

\subsection{Plastic waste reduction and management}

The COVID-19 pandemic has increased reliance on singleuse plastics (for example, increased demand for single-use bags and PPE products), and also led to a reversal of policies on source reduction of single-use plastic products. Under the COVID-19 pandemic, some systemic fragilities in waste management were uncovered. Some statewide, municipal, and corporate entities in the US and Canada suspended or postponed the single-use plastic bans. And since the start of the pandemic, many grocery stores have forbidden the consumers to use their own reusable bags (single-use plastic bags instead) (Vanapalli et al., 2021; Ikiz et al., 2021). Thus, it is necessary to regain the latest progress in phasing out excess single-use plastic. It is particularly important to reduce the demand for new PPE and reuse it instead. PPE reuse is a potential short-term solution during the COVID-19 pandemic, which could reduce waste generation. The United States and Ireland have carried out some work in this area (Rowan and Laffey, 2020).

\subsection{Updating strategies for medical waste management}

Since medical waste management systems are designed for normal operation, the medical waste during an epidemic can far exceed the available capacity. Indeed, the surge in medical waste may greatly bring the pressure on a country's comprehensive deployment capacity. In this critical situation, whether to use MSW incineration capacity to deal with medical waste is still an open question. Some countries have therefore developed auxiliary facilities, such as the fixed, mobile, and coprocessing equipment. However, when using co-processing facilities, the operation must meet the standard emission requirements, in order to avoid secondary health effects. After the pandemic subsides, however, some countries will be faced with the problem of how to deal with these extra capacities. These treatment facilities are unlikely to be transformed into incinerators from which heat energy could be recovered, nor are they likely to be used for MSW. The strategies and plans for emergency 
medical waste disposal will therefore need to be updated both during and after the pandemic.

\section{Conclusions and future outlook}

WHO states that the COVID-19 pandemic will persist for a long time, and all countries are working on prevention plans, as well as vaccine research and development. The spread of the COVID-19 pandemic will also have a longterm impact on environmental sustainability. According to the above results, there is no doubt that the COVID-19 outbreak has greatly increased the amount of medical waste, especially infectious medical waste. In many countries suffering from COVID-19, their waste has an increase with 18\%-425\%. From Jan 22 to Sep 22, 2.9 million tons of COVID-19-related medical waste has been generated.

Meanwhile, the consumers have shifted from worrying about plastic waste's environmental impacts to preferring plastic packaging during the pandemic. The pandemic has also increased their demand for online shopping and food delivery services. These consumption habit changes have without exception resulted in plastic waste management difficulties and a reversal of policies on source reduction of single-use plastics products. The quarantine policies and lockdowns have probably increased the volume of food waste, but perhaps also helped them realize the importance of food waste reduction. Furthermore, any increased food waste in households may have been offset by a reduction outside the household, especially from commercial food services. Even, food loss and waste may actually decrease.

Many countries have adjusted or updated their policies for emergency waste management under the COVID-19 attack. And China can provide valuable lessons from their experiences: building a comprehensive disposal system through a combination of centralized disposal and on-site emergency disposal of medical waste, such as mobile treatment equipment and industrial kilns for medical waste disposal. Apart from medical waste, the collection, recycling, and treatment practices for household waste vary in different countries and cities. Depending on the proportion and possibility of potential infectious waste in MSW, the appropriate strategy should be selected for dealing with this waste.

The pandemic not only changed individuals' lifestyle and consumption patterns but also stimulated more thoughtfulness on the relationships between human and natural environment. This study provides basic information on the effective solid waste management during and after the pandemic. Limited by the current situation, previous studies have focused on the description of the COVID-19 impact on waste generation, while studies on the deeper impacts are still lacking. More investigations are required to evaluate the changes in waste characteristics, overall environmental impacts, consumption of resources and long-term effects. In addition, there are serious questions about whether the previous systems of classification, recycling and resource recovery can be quickly restored, and whether the population will again focus their concern on reducing plastic waste. Issues like these need to be discussed and studied in the future.

Acknowledgements This work was funded by the Science and Technology Development Fund, Macao SAR, China (No. 0062/2020/A).

\section{Reference}

ADEPT (2020). COVID 19 - Waste Survey Results, Week Commencing 18th May. Available online at the website of www.adeptnet.org.uk/ documents/covid-19-waste-survey-results-wc-18th-may (Accessed September 27 2020).

Aldaco R, Hoehn D, Laso J, Margallo M, Ruiz-Salmón J, Cristobal J, Kahhat R, Villanueva-Rey P, Bala A, Batlle-Bayer L, Fullana-IPalmer P, Irabien A, Vazquez-Rowe I (2020). Food waste management during the COVID-19 outbreak: A holistic climate, economic and nutritional approach. Science of the Total Environment, $742: 140524$

AMSA (2020). Waste management and cleaning services in Milan during COVID-19. Available online at the website of www.acrplus. org/images/project/Covid-19/AMSA_Waste_management_during_COVID-19.pdf (Accessed September 27 2020)

Asian Development Bank (ADB) (2020). Managing infectious medical waste during the COVID-19 pandemic. Available online at the website of www.adb.org/publications/managing-medical-wastecovid19 (Accessed September 22 2020)

Basel Convention (2020a). Waste management an essential public service in the fight to beat COVID-19: Basel Convention. Available online at the website of www.basel.int/Implementation/PublicAwareness PressReleases/WastemanagementandCOVID19/tabid/8376/ Default.aspx (Accessed September 22 2020)

Basel Convention (2020b). Healthcare or Medical Waste. Available online at the website of www.brsmeas.org/Portals/4/download.aspx? $\mathrm{d}=$ UNEP-CHW-PUB-Factsheets-Healthcare-MedicalWaste-2020. English.pdf (Accessed September 27 2020)

Basel Convention (2020c). COVID19: Factsheet on Environmentally Sound Management of Medical Waste. Available online at the website of http://www.brsmeas.org/Implementation/MediaResources/NewsFeatures/COVID19Factsheet/tabid/8409/language/enUS/Default.aspx (Accessed September 22 2020)

Brizi A, Biraglia A (2021). "Do I have enough food?" How need for cognitive closure and gender impact stockpiling and food waste during the COVID-19 pandemic: A cross-national study in India and the United States of America. Personality and Individual Differences, 168:110396

Centers for Disease Control and Prevention (CDC) (2020). Clinical Questions about COVID-19: Questions and Answers. Available online at the website of www.cdc.gov/coronavirus/2019-ncov/hcp/ faq.html\#Waste-Management (Accessed October 29 2020)

Chen Y, Guo C (2020). Handbook of emergency disposal and management of medical waste in china. Available online at the 
website of bcrc.tsinghua.edu.cn/en/col/1257152490625/2020/06/22/ 1592835193073.html (Accessed September 27 2020).

China B C R C (2020). Laws and Regulations. Available online at the website of bcrc.tsinghua.edu.cn/en/col/1257152450718/index.html (Accessed September 27 2020).

Clement J (2020). Coronavirus global online traffic impact as of September 2020. Available online at the website of www.statista. com/statistics/1105495/coronavirus-traffic-impact (Accessed September 25 2020)

Dente S M R, Hashimoto S (2020). COVID-19: A pandemic with positive and negative outcomes on resource and waste flows and stocks. Resources, Conservation and Recycling, 161: 104979

Eroglu H (2020). Effects of Covid-19 outbreak on environment and renewable energy sector. Environment, Development and Sustainability: $1-9$

ESCAP (2020). The safe waste treatment for COVID-19, lessons from the Republic of Korea: ESCAP-United Nation Economic and Social Commission for Asia and the Pacific. Available online at the website of www.unescap.org/sites/default/files/200514\%20waste\%20management $\% 20$ for $\% 20$ COVID19\%28edited\%29\%20FINAL.pdf (Accessed October 12020 )

Espejo W, Celis J E, Chiang G, Bahamonde P (2020). Environment and COVID-19: Pollutants, impacts, dissemination, management and recommendations for facing future epidemic threats. Science of the Total Environment, 747: 141314 doi: 10.1016/j.scitotenv.2020.141314

European Centre for Disease Prevention and Control (ECDC) (2020). Infection prevention and control in the household management of people with suspected or confirmed coronavirus disease (COVID19). Available online at the website of www.ecdc.europa.eu/en/ publications-data/infection-prevention-control-household-management-covid-19 (Accessed September 27 2020)

European Commission (2020). Waste management in the context of the coronavirus crisis. Available online at the website of ec.europa.eu/ info/sites/info/files/waste_management_guidance_dg-env.pdf. (Accessed September 27 2020).

Fan Y V, Jiang P, Hemzal M, Klemeš J J (2021). An update of COVID19 influence on waste management. Science of the Total Environment, 754: 142014

Farsaci L (2020). Coronavirus Ireland: cost of PPE for healthcare workers to hit $€ 1$ billion. Available online at the website of www. dublinlive.ie/news/health/coronavirus-ireland-cost-ppe-healthcare18230287 (Accessed September 22 2020)

Feber David L ONordigården Daniel (2020). How the packaging industry can navigate the coronavirus pandemic. Available online at the website of www.mckinsey.com/industries/paper-forest-productsand-packaging/our-insights/how-the-packaging-industry-can-navigate-the-coronavirus-pandemic (Accessed September 25 2020)

Fu W (2020). Wuhan medical waste disposal withstands emergency test. Available online at the website of health.people.com.cn/n1/2020/ 0403/c14739-31660329.html (Accessed September22 2020)

Generalitat de Catalunya (2020). La generació de residus municipals a Catalunya ha caigut un $17 \%$ durant el mes de confinament per la COVID-19. Available online at the website of govern.cat/salapremsa/ notes-premsa/384304/generacio-residus-municipals-catalunya-hacaigut-17-percent-durant-mes-confinament-covid-19 (Accessed Sep- tember 27 2020)

GOV.UK (2020a). Guidance on prioritising waste collection services during coronavirus (COVID-19) pandemic. Available online at the website of www.gov.uk/government/publications/coronavirus-covid19-advice-to-local-authorities-on-prioritising-waste-collections/guidance-on-prioritising-waste-collection-services-during-coronaviruscovid-19-pandemic (Accessed September 27 2020)

GOV.UK (2020b). Cleansing and PPE waste at a healthcare waste management facility: RPS C1. Available online at the website of www.gov.uk/government/publications/storing-or-treating-covid-19cleansing-waste-at-a-healthcare-waste-management-facility-rps (Accessed September 27 2020)

Grodzińska-Jurczak M, Krawczyk A, Jurczak A, Strzelecka M, Rechciński M, Boćkowski M (2020). Environmental choices Vs. Covid-19 pandemic fear - plastic governance re-assessment. Socialist Register, 4(2): 49-66

Hunter (2020). Food Study Special Report. Available online at the website of www.slideshare.net/HUNTERNY/hunter-food-study-special-report-america-gets-cooking-231713331 (Accessed September 27 2020)

Ikiz E, Maclaren V W, Alfred E, Sivanesan S (2021). Impact of COVID19 on household waste flows, diversion and reuse: The case of multiresidential buildings in Toronto, Canada. Resources, Conservation and Recycling, 164: 105111

Ilyas S, Srivastava R R, Kim H (2020). Disinfection technology and strategies for COVID-19 hospital and bio-medical waste management. Science of the Total Environment, 749: 141652

ISS (2020). How to dispose of household waste. Available online at the website of www.iss.it/coronavirus/-/asset_publisher/ 1SRKHcCJJQ7E/content/id/5296303?_com_liferay_asset_publisher_web_portlet_AssetPublisherPortlet_INSTANCE_1SRKHcCJJQ7E_redirect $=$ https $\% 3 \mathrm{~A} \% 2 \mathrm{~F} \% 2 \mathrm{Fwww}$.iss.it $\%$ 2Fcoronavirus\%3Fp_p_id\%3Dcom_liferay_asset_publisher_we (Accessed September 27 2020)

International Solid Waste Association (ISWA) (2020). Waste Management During the COVID-19 Pandemic. Available online at the website of www.iswa.org/iswa/covid-19 (Accessed September 30 2020)

Jribi S, Ben Ismail H, Doggui D, Debbabi H (2020). COVID-19 virus outbreak lockdown: What impacts on household food wastage? Environment, Development and Sustainability, 22(5): 3939-3955

Kampf G, Todt D, Pfaender S, Steinmann E (2020a). Persistence of coronaviruses on inanimate surfaces and their inactivation with biocidal agents. Journal of Hospital Infection, 104(3): 246-251

Kampf G, Todt D, Pfaender S, Steinmann E (2020b). Persistence of coronaviruses on inanimate surfaces and their inactivation with biocidal agents (vol 104, pg 246, 2020). Journal of Hospital Infection, 105(3): 587-587

Klemeš J J, Fan Y V, Tan R R, Jiang P (2020). Minimising the present and future plastic waste, energy and environmental footprints related to COVID-19. Renewable \& Sustainable Energy Reviews, 127: 109883

Kulkarni B N, Anantharama V (2020). Repercussions of COVID-19 pandemic on municipal solid waste management: Challenges and opportunities. Science of the Total Environment, 743: 140693

Lal P, Kumar A, Kumar S, Kumari S, Saikia P, Dayanandan A, Adhikari 
D, Khan M L (2020). The dark cloud with a silver lining: Assessing the impact of the SARS COVID-19 pandemic on the global environment. Science of the Total Environment, 732: 139297

Mihai F C (2020). Assessment of COVID-19 waste flows during the emergency state in Romania and related public health and environmental concerns. International Journal of Environmental Research and Public Health, 17(15): 5439

Ministry of Ecology and Environment of China (MEE) (2020a). The Ministry of Ecology and Environment reported on the treatment of medical waste, medical wastewater and environmental monitoring in China. Available online at the website of www.mee.gov.cn/ywdt/ xwfb/202001/t20200129_761043.shtml (Accessed September 22 2020) (in Chinese)

Ministry of Ecology and Environment of China (MEE) (2020b).The Ministry of Ecology and Environment issued Guide on Management and Technical on Emergency Treatment and Disposal of Medical Waste Caused by COVID-19 (Trial). Available online at the website of www.mee.gov.cn/home/ztbd/2020/dyyqfkzjz/xdbs/sthjb/202003/ t20200331_772201.shtml. (Accessed September 23 2020). (In Chinese)

Ministry of Environment of South Korea (MoE Korea) (2020). Press Release, Minister of Environment, Check the Management of Wastes Related to COVID-19. Available online at the website of me.go.kr/ home/web/board/read.do;jsessionid = RwDT9rf77AYJRhB3t87es + AU.mehome1 ?pagerOffset $=10 \&$ maxPageItems $=10 \& \operatorname{maxIndex}-$ Pages $=10 \&$ searchKey $=$ title $\&$ search Value $=\% \mathrm{EC} \% \mathrm{BD} \% 94 \% \mathrm{~EB} \%$ A $1 \% 9 \mathrm{C} \%$ EB $\% 82 \% 98 \&$ menuId $=286 \&$ org Cd $=\&$ boardId $=$ $1350590 \&$ boardMasterId $=1$ \&boardCategoryId $=$ \&decorator $=$ (Accessed September22 2020)

Ministry of the Environment Government of Japan (MoE Japan) (2020). Guidelines for control on COVID-10 waste. Available online at the website of www.env.go.jp/recycle/waste/sp_contr/infection/coronakoho.html (Accessed September 27 2020)

Minstry of Health and Welfare (MOHW) (2020). The extraordinary measures for Safety Management of Wastes Related to COVID-19 (3rd). Available online at the website of ncov.mohw.go.kr/duBoardList.do?brdId $=2 \&$ brdGubun $=28$. (Accessed September 27 2020)

National Health Commission of China (NHC) (2020). Notice on Environmental Management of Medical Waste Caused by COVID19. Available online at the website of www.nhc.gov.cn/yzygj/s7659/ 202001/6b7bc23a44624ab2846b127d146be758.shtml (Accessed September 22 2020)

Swedish EPA (2020). Avfallshantering kopplat till Coronavirus. Available online at the website of www.naturvardsverket.se/Stod-imiljoarbetet/Vagledningar/Avfall/Farligt-avfall/Avfallshanteringkopplat-till-Coronavirus (Accessed September 27 2020)

Naughton C C (2020). Will the COVID-19 pandemic change waste generation and composition? The need for more real-time waste management data and systems thinking. Resources, Conservation and Recycling, 162: 105050

Nghiem L D, Morgan B, Donner E, Short M D (2020). The COVID-19 pandemic: Considerations for the waste and wastewater services sector. Case Studies in Chemical and Environmental Engineering, 1

Nzediegwu C, Chang S X (2020). Improper solid waste management increases potential for COVID-19 spread in developing countries. Resources, Conservation and Recycling, 161: 104947
Ouhsine O, Ouigmane A, Layati E, Aba B, Isaifan R J, Berkani, M. (2020) Impact of covid-19 on the qualitative and quantitative aspect of household solid waste. Global Journal of Environmental Science and Management, 6(SI), 41-52

OCEANSASIA (2020). No shortage of surgical masks at the beach. Available online at the website of oceansasia.org/beach-maskcoronavirus (Accessed September 27 2020)

Patrício Silva A L, Prata J C, Walker T R, Campos D, Duarte A C, Soares A, Barcelo D, Rocha-Santos T (2020). Rethinking and optimising plastic waste management under COVID-19 pandemic: Policy solutions based on redesign and reduction of single-use plastics and personal protective equipment. Science of the Total Environment, 742: 140565

Patrício Silva A L, Prata J C, Walker T R, Duarte A C, Ouyang W, Barcelo D, Rocha-Santos T (2021). Increased plastic pollution due to COVID-19 pandemic: Challenges and recommendations. Chemical Engineering Journal, 405: 126683

Peng J, Wu X, Wang R, Li C, Zhang Q, Wei D (2020). Medical waste management practice during the 2019-2020 novel coronavirus pandemic: Experience in a general hospital. American Journal of Infection Control, 48(8): 918-921

Penteado C S G, Castro M A S D(2021). Covid-19 effects on municipal solid waste management: What can effectively be done in the Brazilian scenario? Resources, Conservation and Recycling, 164: 105152

PeRKINS Coie (2020). Managing COVID-19 Wastes. Available online at the website of www.perkinscoie.com/en/news-insights/managingcovid-19-wastes.html. (Accessed September 27 2020)

Prata J C, Silva A L P, Walker T R, Duarte A C, Rocha-Santos T (2020). COVID-19 pandemic repercussions on the use and management of plastics. Environmental Science \& Technology, 54(13): 7760-7765

Ragazzi M, Rada E C, Schiavon M (2020). Municipal solid waste management during the SARS-COV-2 outbreak and lockdown ease: Lessons from Italy. Science of the Total Environment, 745: 141159

Rahman M M, Bodrud-Doza M, Griffiths M D, Mamun M A (2020). Biomedical waste amid COVID-19: Perspectives from Bangladesh. Lancet. Global Health, 8(10): e1262

Ramteke S, Sahu B L (2020). Novel coronavirus disease 2019 (COVID19) pandemic: Considerations for the biomedical waste sector in India. Case Studies in Chemical and Environmental Engineering, doi. org/10.1016/j.cscee.2020.100029

Rhee S W (2020). Management of used personal protective equipment and wastes related to COVID-19 in South Korea. Waste Management \& Research, 38(8): 820-824

Rowan N J, Laffey J G (2020). Unlocking the surge in demand for personal and protective equipment (PPE) and improvised face coverings arising from coronavirus disease (COVID-19) pandemic: Implications for efficacy, re-use and sustainable waste management. Science of The Total Environment, doi.org/10.1016/j.scitotenv.2020.142259

Rupani P F, Nilashi M, Abumalloh R A, Asadi S, Samad S, Wang S (2020). Coronavirus pandemic (COVID-19) and its natural environmental impacts. International Journal of Environmental Science and Technology 17:4655-4666

Saadat S, Rawtani D, Hussain C M (2020). Environmental perspective of 
COVID-19. Science of the Total Environment, 728: 138870

Sarkodie S A, Owusu P A (2020a). Global assessment of environment, health and economic impact of the novel coronavirus (COVID-19). Environment, Development and Sustainability: 1-11

Sarkodie S A, Owusu P A (2020b). Impact of COVID-19 pandemic on waste management. Environment, Development and Sustainability,

Sharma H B, Vanapalli K R, Cheela V S, Ranjan V P, Jaglan A K, Dubey B, Goel S, Bhattacharya J (2020). Challenges, opportunities, and innovations for effective solid waste management during and post COVID-19 pandemic. Resources, Conservation and Recycling, 162: 105052

Somani M, Srivastava A N, Gummadivalli S K, Sharma A (2020). Indirect implications of COVID-19 towards sustainable environment: An investigation in Indian context. Bioresource Technology Reports, 11

Finnish Goverment (2020). Suositukset turvaamaan sujuva jätehuolto koronaviruksesta huolimatta - jätteiden lajitteluun ei tarvita muutoksia kodeissa. Available online at the website of valtioneuvosto.fi/-/ suositukset-turvaamaan-sujuva-jatehuolto-koronaviruksesta-huolimatta-jatteiden-lajitteluun-ei-tarvita-muutoksia-kodeissa (Accessed September 27 2020)

Statista (2020). Coronavirus: impact on the retail landscape in the U.S.Statistics \& Facts. Available online at the website of www.statista. com/topics/6143/coronavirus-covid-19-impact-on-the-retail-landscape-in-the-us/\#dossierSummary_chapter1 (Accessed September 25 2020)

Statistics Korea (2020). Online Shopping in March 2020. Available online at the website of http://kostat.go.kr/portal/eng/pressReleases/ $1 /$ index $\cdot$ board bmode $=$ read $\& b S e q=\& a S e q=382257 \&$ pageNo $=$ $1 \&$ rowNum $=10 \&$ navCount $=10 \&$ currPg $=\&$ searchInfo $=\&$ sTar get $=$ title\&sTxt $=($ Accessed September 25 2020)

Texas Commission on Environmental Quality (TCEQ) (2020). COVID19: Waste Disposal Guidance. Available online at the website of www.tceq.texas.gov/response/covid-19/waste-disposal-guidance. (Accessed October 2020).

The Environmental Protection Bureau (DSPA) Macao SAR (2020). Enviormental data. Available online at the website of www.dspa.gov. mo/envdata.aspx (Accessed October 27 2020)

The State Council Information Office of China (SCIO) (2020). Press conference on strengthening comprehensive treatment of medical waste and environmental protection. Available online at the website of www.scio.gov.cn/xwfbh/gbwxwfbh/xwfbh/wsb/Document/ 1675174/1675174.htm. (Accessed September 22 2020)

Times of India (TOI) (2020). 350 tonnes of trash disappear from streets of Ahmedabad. Available online at the website of timesofindia. indiatimes.com/articleshow $/ 75039037 . \mathrm{cms}$ ?utm_source $=$ contentofinterest\&utm_medium $=$ text\&utm_campaign $=$ cppst $\quad$ (Accessed September 22 2020)

UNEP (2018). Legal Limits on Single-Use Plastics and Microplastics: A Global Review of National Laws and Regulations

UNEP (2020a). COVID-19 Waste management Factsheets. Available online at the website of www.unenvironment.org/resources/factsheet/ covid-19-waste-management-factsheets. (Accessed September 22 2020).

UNEP (2020b). Compendium of Technologies for Treatment/Destruction of Healthcare Waste. Available online at the website of www. unep.org/news-and-stories/story/healthcare-waste-what-do-it (Accessed September 22 2020)

UNEP (2020c). Waste Management during the COVID-19 Pandemic: from response to recovery. Available online at the website of www. unenvironment.org/resources/report/waste-management-duringcovid-19-pandemic-response-recovery (Accessed September 22 2020).

UNICEF (2020a). Water, sanitation, hygiene and waste management for COVID-19: technical brief. Available online at the website of apps. who.int/iris/handle/10665/331305 (Accessed September 22 2020)

UNICEF (2020b). Water, sanitation, hygiene, and waste management for the COVID-19 virus: interim guidance. Available online at the website of apps.who.int/iris/bitstream/handle/10665/333560/WHO2019-nCoV-IPC_WASH-2020.4-chi.pdf (Accessed September 22 2020)

Vanapalli K R, Sharma H B, Ranjan V P, Samal B, Bhattacharya J, Dubey B K, Goel S (2021). Challenges and strategies for effective plastic waste management during and post COVID-19 pandemic. Science of the Total Environment, 750: 141514

Wang J, Shen J, Ye D, Yan X, Zhang Y, Yang W, Li X, Wang J, Zhang L, Pan L (2020). Disinfection technology of hospital wastes and wastewater: Suggestions for disinfection strategy during coronavirus Disease 2019 (COVID-19) pandemic in China. Environmental Pollution, 262: 114665

ACR (2020). La Agencia de Residuos de Cataluña ha establecido diferentes opciones para tratar los residuos sanitarios en el periodo COVID-19. Available online at the website of residus.gencat.cat/es/ actualitat/noticies/detall/residus-sanitaris-COVID19-00001 (Accessed September22 2020)

Waste Minz (2020). Waste collections around the world during the COVID-19 crisis. Available online at the website of www.wasteminz. org.nz/news-events/covid-19/wasteminz-covid-19-blog/waste-collections-around-the-world-during-the-covid-19-crisis/. (Accessed September 27 2020).

Wasteadvantage (2020). The impact of COVID-19 on the waste and recycling industry. Available online at the website of wasteadvantagemag.com/the-impact-of-covid-19-on-the-waste-and-recyclingindustry (Accessed September 27 2020)

WHO (2018). Medical waste, Important facts. Available online at the website of www.who.int/zh/news-room/fact-sheets/detail/healthcare-waste (Accessed September 22 2020)

WHO (2020a). Q\&A on coronaviruses (COVID-19). Available online at the website of www.who.int/news-room/q-a-detail/q-a-coronaviruses (Accessed September 22 2020)

WHO (2020b). Shortage of personal protective equipment endangering health workers worldwide. Available online at the website of www. who.int/news-room/detail/03-03-2020-shortage-of-personal-protective-equipment-endangeringhealth-workers-worldwide (Accessed September 22 2020)

WHO (2020c). Coronavirus disease (COVID-19) Situation dashboard. Available online at the website of who.sprinklr.com (Accessed September 22 2020)

Worldometer (2020). COVID-19 coronavirus pandemic. Available online at the website of www.worldometers.info/coronavirus/\#countries\%3C;\%20accessed\%2008.04 (Accessed September 22 2020)

Wuhan Municipal Health Commission (MHC) (2020). Outbreak 
notification. Available online at the website of wjw.wuhan.gov.cn/ ztzl_28/fk/yqtb (Accessed September 23 2020)

Yang L, Yu X, Wu X, Wang J, Yan X, Jiang S, Chen Z (2021). Emergency response to the explosive growth of health care wastes during COVID-19 pandemic in Wuhan, China. Resources, Conservation and Recycling, 164: 105074
Zambrano-Monserrate M A, Ruano M A, Sanchez-Alcalde L (2020). Indirect effects of COVID-19 on the environment. Science of the Total Environment, 728: 138813

Zand A D, Heir A V (2020). Emerging challenges in urban waste management in Tehran, Iran during the COVID-19 pandemic. Resources, Conservation and Recycling, 162: 105051 